\title{
Health Care and Social Change in the United States A Mixed System, A Mixed Blessing
}

\author{
Bruce Fetter
}

$\mathrm{F}$ or most of human history, the health of any society did not depend much on its biomedical healing system. Physicians could cure or assuage a limited sufficient grounding in experimental science to allow the systematic treatment of disease. Indeed, in 1880, when the United States entered what is commonly known as the mortality transition, its biomedical establishment was weaker than those of most nations in Western and Central Europe. In order to understand changes in the health of Americans, one must consider medical factors as well as political and cultural ones. Indeed, the importance of non-biomedical considerations has persisted to the present in American health.

This essay will analyze the relationship between health and society in the United States over two long periods, from 1880 to 1930 and from 1930 to the present. It will identify those forces that contributed to better health and longer life as well as those problems that had to be addressed. The paper will also consider inequalities in health among Americans. On the basis of these generalizations, the U.S. experience can be made comparable to that of other countries.

\section{Transition America, 1880-1930}

The United States entered the demographic transition in the 19th century. Fertility levels began to fall early in the century, but mortality levels did not consistently decline until the 1880s. On the surface, America's mortality decline was the product of the country's social assets By 1880 the United States was one of the wealthiest countries in the world, where even unskilled workers could earn food and shelter more easily than in their European former homelands. It was a democracy in which all adult men had the right to vote. Its traditions of freedom of association led to the establishment of fraternal organizations which offered their members 
Figure 1. Increases from international migration as percent of total increase by decade 1840-1990.

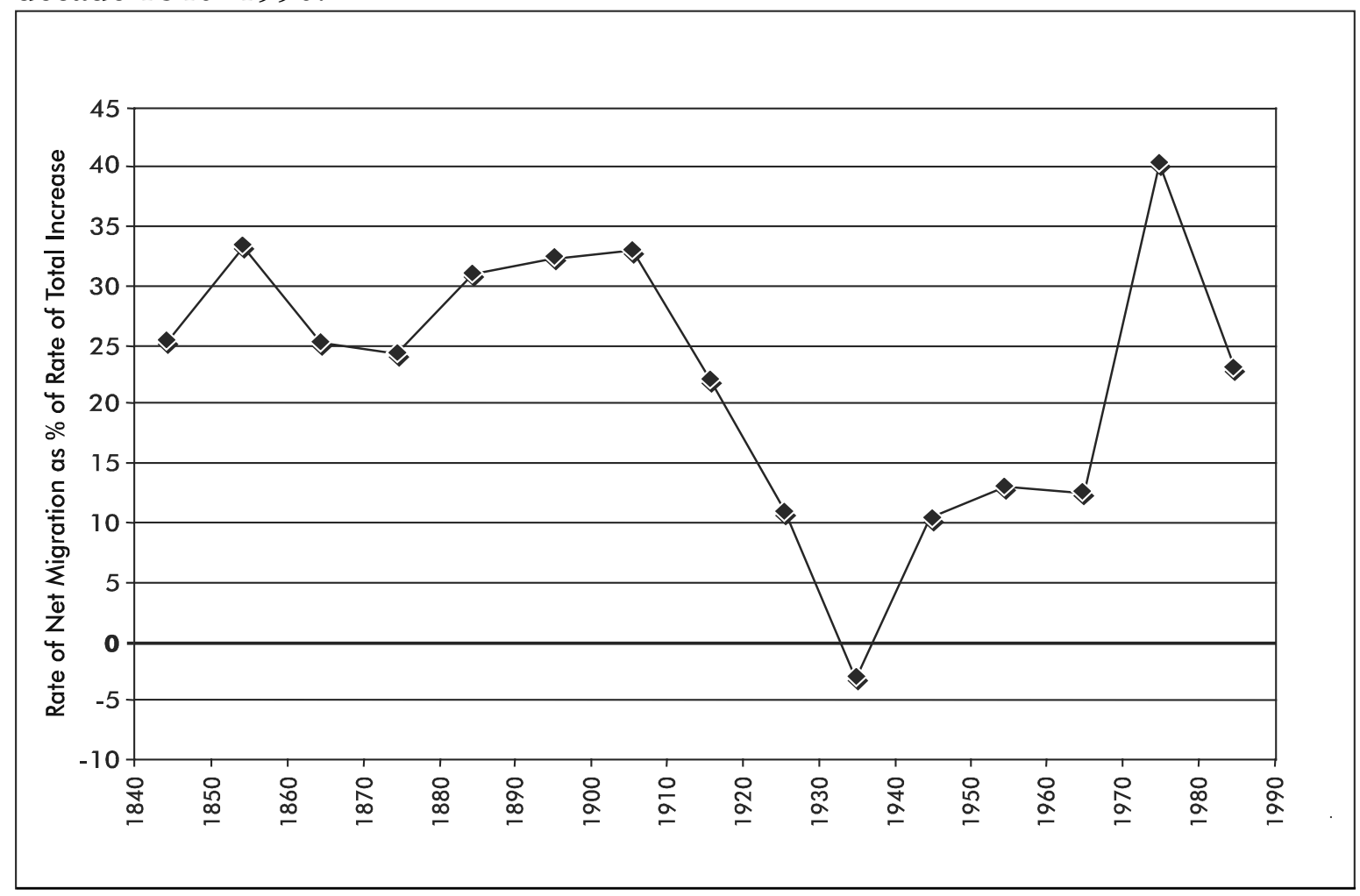

Source: Haines and Steckel, 2000, p 700.

insurance to cover the costs of death and disability. On the negative side of the side of the balance sheet, however, lay a series of obstacles to be overcome. America's industrial cities were every bit as polluted as those of Europe. It lacked a highly trained medical profession. Its constitutional system raised substantial barriers to government action in health care. Finally, its society was riven along lines of race, region, and gender.

Before proceeding to the specifics of the health of Americans, let us explore its social setting. America's wealth has always made it a magnet for migration. Immigration has exceeded emigration for all decades in U.S. history except for the 1930s. Between 1840 and 1920, net migration accounted for well over a quarter of total population increase.' One can only conclude that immigrants came to the United States because life there was better than at home.Voluntary associations played an important role in the efforts of Americans to protect their lives and health. Perhaps, as Robert Putnam² suggests, U.S. civic engagement has served as an

1 M. R Haines and R. H. Steckel, A Population History of North America (Cambridge, Cambridge University Press, 2000), 700, Table A.2

2 Robert Putnam, Bowling Alone: The Collapse and Revival of American Community, (New York: Simon \& Schuster, 2000). 
alternative to "passive reliance on the state". Civic associations, by providing their members with social capital, could have played a key role in the reduction of mortality levels that took place between 1880 and 1930. David Beito ${ }^{3}$ has shown that during the late nineteenth century, a number of fraternal organizations such as the Eagles, Moose, and Foresters collectively hired doctors to care for their members, and, in the case of the Moose, members' families. This "lodge practice" was comparable to the medical services provided by friendly societies in England. ${ }^{4}$ Unfortunately for the American fraternal associations, however, the U.S. medical profession attacked these collective contracts, belittling the doctors who accepted them as ignorant and unprofessional. ${ }^{5}$ These attacks occurred at the time of the great reform of U.S. medical training which roughly coincided with World War I. ${ }^{6}$ The fraternal associations, with the exception of those for black people in New Orleans, abandoned lodge practice, leaving their members to arrange for medical treatment individually. In addition, Beito shows that the fraternal associations suffered two further blows during the Depression. Unemployed members could no longer afford to pay their dues. The enactment of the Social Security Act of 1935, moreover, deprived them of their insurance clientele, because the federal government began to provide the social insurance that had previously only been available through private vendors such as the fraternal associations and commercial insurance companies.

In contrast to America's material and organizational wealth, other late $19^{\text {th }}$ century social realities militated against longer life. The first was the abysmal condition of American cities described by Haines as "virtual charnel houses." Urban political leaders embarked on extensive public works to clean up the microenvironment. The task proved too great for politicians alone; they found that they needed effective local bureaucracies and trained technicians, especially engineers and doctors to build a health-promoting infrastructure. The major causes of death were water-borne diarrheal diseases. ${ }^{8}$ Scientists, even before they could

3 David Beito, From Mutual Aid to the Welfare State: Fraternal Societies and Social Services, 1890-1967 (Chapel Hill, University of North Carolina Press, 2000).

4 J. C. Riley, Sickness, Recovery, and Death (Iowa City, University of Iowa Press, 1989); H. Southall, 'Ageing, health and ending with: A study of life cycle and life chances among 19th century British artisans'. Presented to the International Congress of Historical Sciences, Beijing, 1995.

5 Beito, (2000).

6 K. M. Ludmerer, Learning to Heal: The Development of American Medical Education (New York, Basic Books, 1985).

7 M. R. Haines, 'The urban mortality transition in the United States, 1800-1940', Annales de démographie historique, 2001-1:33-64, (2001), 37.

8 E. Meeker, 'The improving health of the United States: 1850-1915', Explorations in Economic History, 9 (1972), 353-373; E. Meeker, 'The social rate of return on investment in public health, 1880-1910', Journal of Economic History, 34 (1974), 392-421; G. Condran, 
draw a definitive link between microorganisms and disease, recognized that polluted waters were poisoning American cities. They therefore embarked on massive public works that built an infrastructure of reservoirs for filtering water, pipes for distributing it, sewers to remove liquid waste, and dumps to receive solid waste. These public works in turn reduced the incidence of water- and insect-borne diseases in urban areas, allowing the survival of babies who would otherwise have died.

Unfortunately, the U.S. medical profession of the 1880s, although relatively large in numbers, had little capacity to deal with Americans' health problems. Unlike the more settled societies of Europe, Americans did not inherit a sound system for the training of doctors. Most American physicians were trained at proprietary schools of medicine whose instruction lasted less than a year. As late as 1904, Americans were spending roughly four times as much on patent medicines as they were on physicians.' The first modern medical school, Johns Hopkins, did not open until 1893, and scientific standards of medical education were not generally established until the Flexner report of 1910, which forced one-fifth of the nation's medical schools to close their doors. ${ }^{10}$ The proportion of physicians per 100,000 population actually dropped by nearly a third from 171 in 1880 to 125 in $1930 .{ }^{11}$ The new physicians were usually trained in university hospitals that established high standards for patient care and medical education.

The transformation of U.S. medicine in the early twentieth century differed from that of European states, however, in a fundamental way. In Europe, state agencies monarchs, parliaments, and universities - played a central role in the establishment of scientific medicine. In the United States, by contrast, the central government's role was relatively minor. This inaction was deeply rooted in American political practice. The 1787 constitution calls for a separation of powers between the federal government and the states, which retain sovereignty in all matters not expressly

'Declining mortality in the United States in the late nineteenth and early twentieth centuries', Annales de Démographie Historique, (1987), 119-141; M. V. Melosi, The Sanitary City: Urban Infrastructure in America from Colonial Times to the Present (Baltimore, Johns Hopkins, 2000); L.P. Cain and E. J. Rotella, 'Death and spending: Urban mortality and municipal expenditure on sanitation', Annales de démographie historique, 2001-1, (2001), 139-154.

9 Calculations based on J. H. Young, The Toadstool Millionaires: A Social History of Patent Medicine in America before Federal Regulation (Princeton, Princeton University Press, 1961), 176; Ludmerer, (1985), 178; P. Starr, The Social Transformation of American Medicine (New York, Basic Books, 1987), 142.

10 Ludmerer, (1985).

11 Historical Statistics of the United States: Millenial Edition (Preprint, Cambridge, Cambridge University Press, 1999), Table A25. 
Figure 2. Number of physicians per 100,000 in US population 1850-1990.

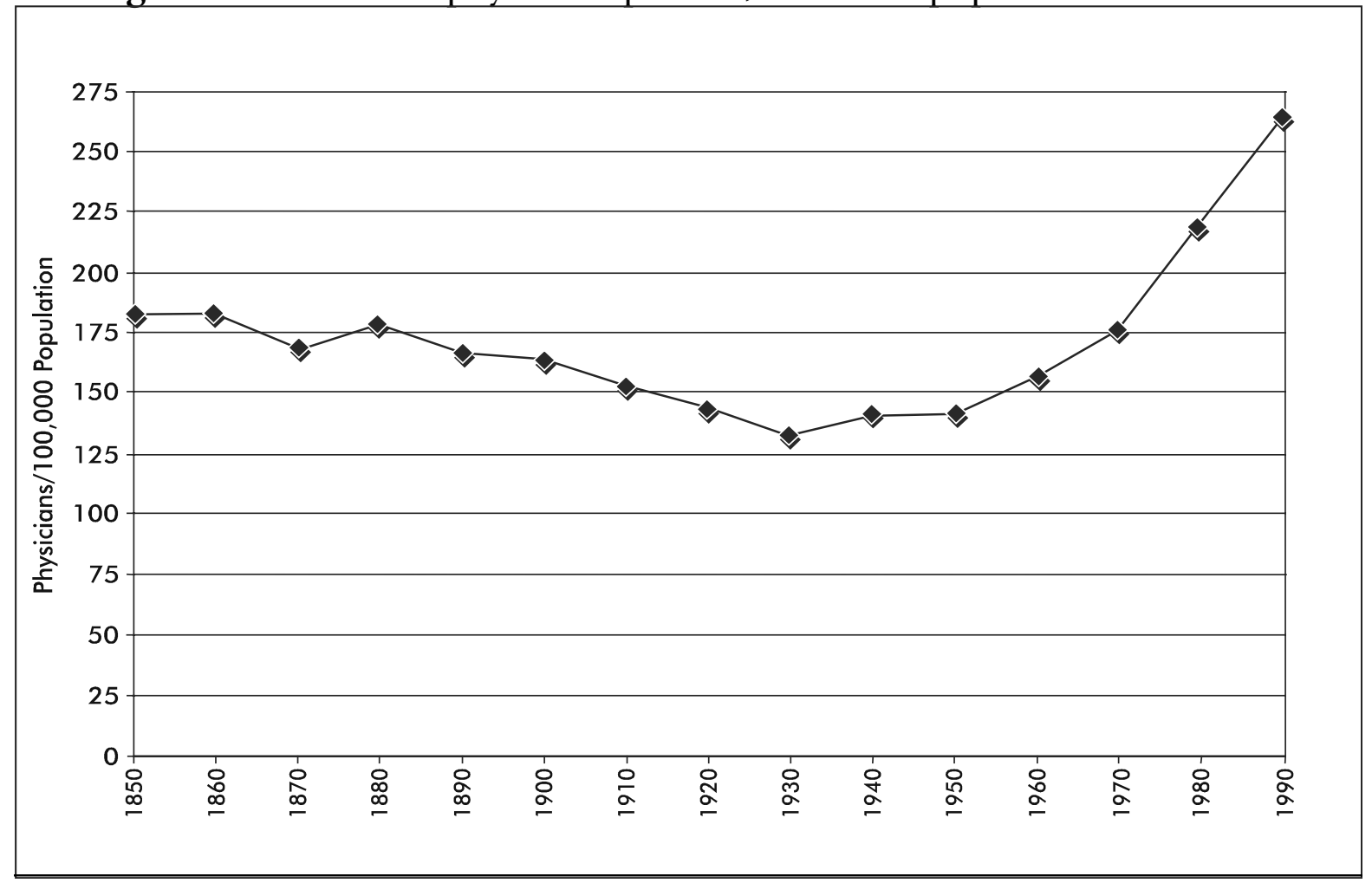

Source: Historical Statistics of the United States: Millenial edition, 1999 preprint Table A25.2.

delegated to the central government. ${ }^{12}$ In addition to slavery, the Civil War of 186165 was fought over the rights of the states. Even though the Southern states, which had sought to secede from the Union, had been defeated militarily, a strong element of suspicion of the federal government remained in North as well as South. In the 1870s, Southern states resisted federal efforts to combat a yellow fever epidemic; $^{13}$ as late as the 1920 s, Massachusetts refused federal money for poor women and children on the grounds that such payments were subversive of the state's authority. ${ }^{14}$

The federal government was, when compared to its European counterparts, extremely slow to act in health matters. Congress did not pass a general national quarantine law until 1893. The Public Health Service did not emerge as a separate agency until 1912. ${ }^{15}$ Most American health expenditures were in the private sector. The first systematic inquiry into national health expenditures reveals that

12 R. Apple, Reaching Out to Mothers: Public Health and Child Welfare. Evening Lecture Series 5 (Sheffield, European Association for the History of Medicine and Health Publications, 2002).

13 M. Humphreys, Yellow Fever and the South (Baltimore, Johns Hopkins, 1992).

14 B. G. Rosenkrantz, Public Health and the State: Changing Views in Massachusetts (Cambridge MA, Harvard, 1972).

15 F. Mullan, Plagues and Politics: The Story of the United States Public Health Service (New York, Basic Books, 1989). 
Americans in 1929 were spending a respectable $3.4 \%$ of the GDP on health, but the government's share was only $13.9 \%$ of that total, most of it by states and localities for mental and tuberculosis hospitals. A full $86.1 \%$ came from private sources. ${ }^{16}$

Despite these many deficiencies, the health of Americans improved substantially in the period between 1880 and 1930. A tabulation of these improvements, however, shows that some Americans benefited more than others. Let us begin with the issue of mortality. Haines ${ }^{17}$ offers two measures of mortality, life expectancy at birth [e0] the Infant Mortality Rate [IMR], calculated as a ratio of infant deaths per thousand live births per annum. For white men, the life expectancy rose from 40.5 years in 1880-84 to 60.9 years in 1930, while that for black men rose from somewhere in the mid-thirties to 48.5 in that same period. Disparities between the life expectancies of the two groups actually widened to the point that whites at birth had a life expectancy that was $25 \%$ longer than blacks.

Similar trends can be found in the Infant Morality Rate. That for white infants fell from 214.8 per thousand in 1880 to 60 in 1930; that for black infants fell from approximately 230 in 1880 to 99.0 in $1930 .{ }^{18}$ Even at the end of this period, black infants in their first year were $50 \%$ more likely to die than white ones.

U.S. racial categories are not the only ones subject to disparities. Geography also made a difference. At the turn of the century, rural white males had a life expectancy at birth ten years longer than that of urban white males, a discrepancy that fell to 2.6 years in 1940. Nearly three-fourths of the difference between rural and urban life expectancy disappeared in the first four decades of the twentieth century.

Another factor affecting life expectancy was gender, but during the early years of the century it became more pronounced. In 1900 white women's life expectancy was 3.7 years longer than that of white men; by 1940 the discrepancy rose to 5.2 years. As far as Infant Mortality Rates are concerned, urban boy babies in 1900 experienced a reported mortality rate nearly fifty percent higher than that of girls: 151.0 per thousand as opposed to 101.0. By 1930 the gap had declined substantially; boys' rate stood at 69.9 per thousand versus girls' 55.2. ${ }^{19}$

Country of birth also played a changing role in mortality. Native-born white men and women tended to experience lower mortality levels than foreign born. The standardized death rates for native-born white men [between the ages of 25 and 64 calculated from statistics derived from industrial insurance policies sold to working

16 Based on Committee on the Costs of Medical Care 1932, Medical Care for the American People (Chicago, University of Chicago Press), 14, 52; and retrospective GDP estimates.

17 M. R. Haines, 'The white population of the United States, 1790-1920', in A Population History of North America, Haines and Steckel (2000), 308.

18 Haines and Steckel, (2000), 696-699.

19 Haines, (2001), 46, 52. 
Figure 3. US black and white life expectancy at birth and infant mortality rates $1850-1990$.

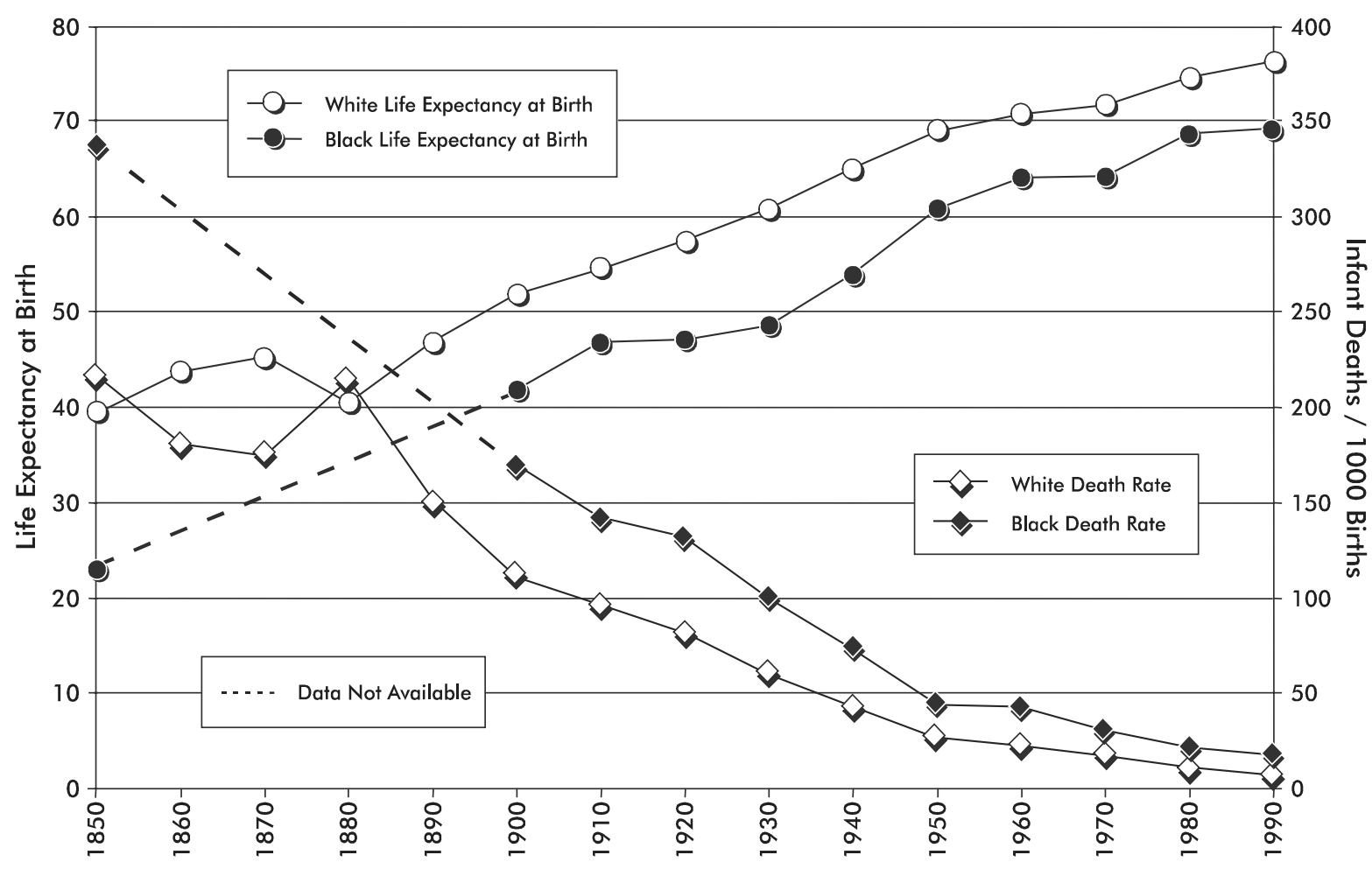

Source: Haines and Steckel, 2000, p 696.

class Americans] was 12.7 per thousand as opposed to 15.8 per thousand for foreign born men. By the same measure, the rate for native born white women was 11.5 per thousand compared with 14.9 for foreign-born women. Thus, foreign-born adults experienced mortality levels roughly twenty percent higher than those of native born whites. All groups' mortality fell over the next forty years: native born men had a mortality rate of 7.9 per thousand while that for foreign men was 8.1. The mortality rate for women in 1940 was lower still: native born had a mortality rate of 6.3 per thousand while that for foreign born was 7.0. In effect, the gender gap proved more durable than that of national origins. ${ }^{20}$

Latinos, an immigrant group that would by the end of the century become a significant proportion of the U.S. population, did not initially share this convergence with the native-born population. In 1910, they constituted a little over one percent of the total population. Exact numbers are difficult to come by, because the population was enumerated by race and not by native language. Recent studies

20 L. I. Dublin, A .J. Lotka and M. Spiegelman, Length of Life: A Study of the Life Table (New York, Ronald Press, 1949), 57. 
Figure $4 \mathbf{a}-\mathbf{b}$. Standardized death rates per 1000 for native and foreign born, ages 25-64, by decade 1900-1940. a) males b) females.
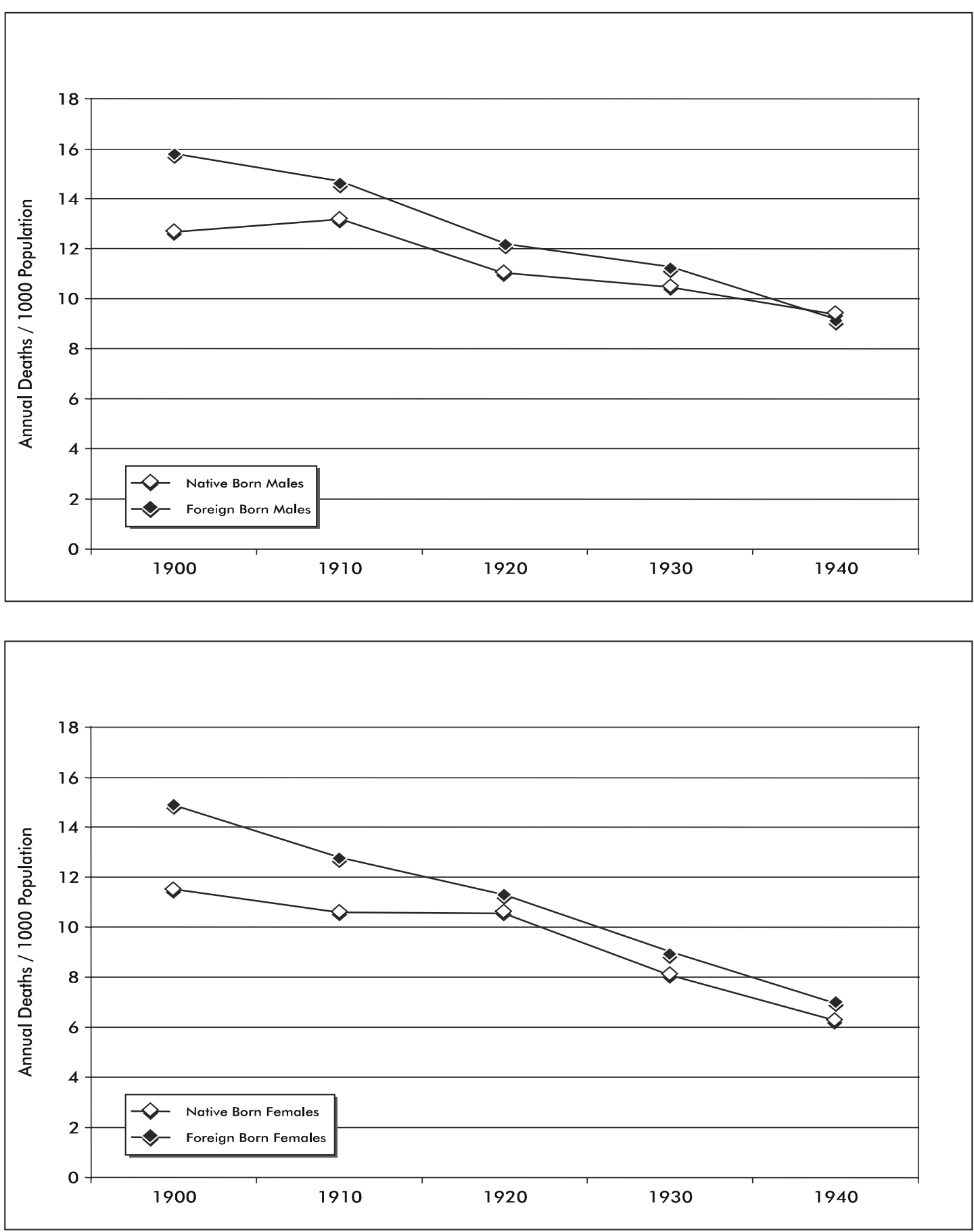

Source: Dublin, Lotka and Spiegelman, 1949, p 57. 
have shown that at that time the mortality of their infants was more than $50 \%$ higher than that of whites, roughly the same as that for blacks. The disparity between Latinos and non-Hispanics remained at this same order of magnitude to the end of the 1930s. ${ }^{21}$

Let us now discuss the reasons for these discrepancies of race, gender, urban residence, and country of birth. Conditions improved for all groups; on the average, they lived longer in 1940 than they did in 1880. By 1940 some gaps had closed. City-dwellers were living almost as long as rural people. The life expectancies of the foreign-born were catching up to those of the native-born, as were those of boy babies compared with those of girl babies. Haines ${ }^{22}$ represents the consensus in attributing (urban) mortality reduction to "significant public works improvements and advances in public health and, eventually, medical practice." In other social groups, however, disparities persisted. Blacks and Latinos lived less long than whites, and women were outliving men by increasing margins.

The causes of these changes in relative privilege were not necessarily the same for all categories. Let us first consider race, that canyon dividing American society. The twenty-year increase in life expectancy enjoyed by white Americans in only sixty years is nearly unique in demographic history. White and Preston ${ }^{23}$, by projecting the effect of various mortality rates, conclude that almost all of the improvement in life expectancy between 1900 and 1930 can be attributed to lower death rates for infants and young children.

But did mortality decline among white infants for the same reasons as among black ones? After all, during those years they did not live in the same regions: whites were more likely to live in the urbanized North, while blacks were concentrated in the rural South. The complication here was that although rural areas were healthier than cities, Southern rural areas were far less healthy than northern ones. The American South lived under a heavier disease burden than the North, because it was subject to diseases which survived better in semi-tropical environments than in temperate ones: malaria, yellow fever, and hookworm in particular.

Urban areas, moreover, had better access than the countryside to the new generation of university-trained physicians. City children had greater access both to physicians and to public health officials. These groups became agents for the administration of vaccines to prevent disease. Early tangible evidence of this came

21 Myron P. Gutmann et al., 'Intra-ethnic diversity in Hispanic child mortality, 18901910', Demography 37,4 (2000), 467-475; D. Forbes and W. P. Frisbie, 'Spanish surname and Anglo infant mortality: Differentials over half a century', Demography, 28,4 (1991), 639-660.

22 Haines, (2001)

23 K. M. White and S. H. Preston, 'How many Americans are alive because of twentiethcentury improvements in mortality?', Population and Development Review, 22,3 (1996), 415-429. 
with diphtheria, one of the first vaccine-preventable illnesses of childhood. Its incidence fell from a high of 190 per 100,000 in 1921 to 11.8 in $1940 .^{24}$

White children may also have benefited from vaccination against smallpox. For the country as a whole, the incidence of smallpox fell from a high of 66.4 per 100,000 in 1914 to 2.1 in $1940^{25}$, but this decline camouflages other trends in the occurrence of the disease. The real killer was the acute subspecies of the virus, Variola major, which in the eighteenth century had devastated many parts of the world with disfigurement and mortality levels of up to thirty percent. Jennerian vaccination with Vaccinia, a virus closely related to Variola, protected many from the disease, especially after the 1840s when periodic revaccination was introduced. The procedure became even more popular when risky arm-to-arm vaccination was replaced by a safer vaccigen derived from calves.

In the United States, however, not everyone was vaccinated. Prevailing racist beliefs inhibited arm-to-arm vaccination of African Americans, a taboo continued even after that form of vaccination was discontinued. Salvation for African Americans came in the form of an epidemic of Variola minor, a milder subspecies of the virus that produces a much lower mortality, but which nonetheless provides immunity against Variola major. Beginning in 1896, Variola minor spread through the United States, infecting African-Americans and leaving them immune to the more virulent form of smallpox. The racially divergent paths to ending the smallpox danger can be seen in the number of cases of the two strains. Variola major fell from 10,000 cases a year in 1902 to 0 in 1928, while reported cases of Variola minor peaked at 109,000 cases in 1920, falling back to a still substantial 48,000 cases in $1930 .{ }^{26}$ One can therefore conclude that the decline of Variola major among whites resulted from public health efforts to vaccinate susceptible white people and to isolate active cases, while the decline of Variola minor among blacks was the unplanned result of a largely benign epidemic. If access to physicians had been black people's only defense against smallpox, the mortality gap between the races would have been even broader than it was.

The other major inequity in American society was that between men and women. Explanations for women's greater life expectancy vary from the biological to the behavioral. Females outlive males in most forms of animal life. Men, historically the main breadwinners in American families, were reluctant to take time off from work in order to get medical help. Conversely, women have been more

24 Historical Statistics of the United States: Millenial Edition (Preprint, Cambridge, Cambridge University Press, 1999), Table A 37.

25 Historical Statistics (1999), Table A 37.

26 C. Chapin, 'Variation in type of infectious disease as shown by the history of smallpox in the United States, 1895-1912', Journal of Infectious Diseases, 13,2 (1913), 171-196; C. Chapin, 'Permanency of the mild type of smallpox', Journal of Preventive Medicine, 6 (1932), 273-320. 
willing to seek medical help when feeling sick. A single factor explanation for women's longer life is obviously inadequate.

The convergences and divergences in American health between 1880 and the Great Depression demonstrate the societal priorities of the time. Americans wanted to close the health gap between cities and the countryside, just as they wanted to prevent the avoidable death of children. As a nation founded by immigrants, they wanted new arrivals to enjoy the same health as other citizens. Their commitment to equality in health for blacks and Latinos, by contrast, was less urgent. As for the shorter life spans of men, Americans focused their private and public resources on the consequences of the loss of a breadwinner rather than on the means of extending that breadwinner's life.

\section{Post-transition America, 1930-2003}

Since 1930, U.S. society has been transformed in a number of ways that affect American health. Some of these changes include those in the basic demographic indicators: fertility, mortality, and migration. Others involve the growing role of the government in the economy, the provision of biomedical health care, and the role of private initiative.

As far as demography is concerned, mortality continued the decline begun in the 1880s. In the immediate aftermath of World War II, fertility rose, creating a cohort of "baby boomers" succeeded in the next generation by a return to lower birthrates. Migration, which had slowed to a trickle, resumed after the war and peaked in the 1970s and 1980s. Serious divisions remained between the races and sexes in American society.

Life expectancy continued to rise, but more slowly than in the transition period. The combined life expectancy at birth for white males and females increased from 60.9 years in 1930 to 76.1 years in 1990, a smaller percentage of improvement than in the earlier period. For black males and females the combined life expectancy at birth rose from 48.5 to 69.1 years. [See Figure 3.] Part of this deceleration was a statistical artifact in that the greatest increases in life expectancy at birth occur when mortality decreases in infancy and early childhood. Since these components of overall mortality were already reduced during the earlier period, declines in mortality at higher ages did not affect life expectancy to the same degree. According to White and Preston ${ }^{27}$, most reductions between 1930 and 1960 affected older children and young adults between the ages of five and fifty. Between 1960 and 1990 most improvements came to adults over the age of fifty. These advances

27 White and Preston, (1996). 
resulted from unprecedented improvements in medical care due to the introduction of new pharmaceuticals [antibiotics between the late 1930s and the mid-1950s and in the 1980s and 1990s new drugs whose action obviated the necessity of certain surgeries]. Also new procedures were developed to deal with heart disease, stroke and cancer. To take one rough indicator of the utility of these new diagnostic and curative procedures, the five-year survival rate for all diagnosed cancers rose from $46.3 \%$ in 1973 to $60.2 \%$ in $1991 .^{28}$

During this same period black life expectancy rose nearly as quickly as that of whites during the transition period. This increase continued across the decade of the Great Depression and despite the Great Migration from the rural South to the urban North. Blacks nonetheless experienced less favorable life chances. ${ }^{29}$ Their life expectancies at birth were still 6.7 years less than those for whites. IMRs fell to historically low levels for both racial groups [7.6 per thousand for whites and 18 per thousand for blacks]..$^{30}$ [See Figure 3.]

Indeed, one might well argue that disparities between blacks and whites ought to be measured by their absolute magnitude rather than by percentages. The infant mortality rate of black babies, less than two percent per year, is thus of the same magnitude as that of whites. The life expectancy of the blacks of all ages, compared with that of whites, by contrast has remained substantial. We therefore need to inquire further into the reasons that the mortality of black adults has remained so much higher than that of whites.

We might have expected a narrowing of the racial gap, because of the Great Migration, which brought millions of African-Americans from the overtly discriminatory South to cities of the Northeast and Midwest. Indeed, the regional gap between North and South diminished as a result of the eradication of malaria in the South. ${ }^{31}$ Northern cities, moreover, became at least as segregated as the old Confederacy, and African-Americans continued to suffer from poverty and discrimination. These conditions adversely affected their lives and health.

Another cause for the persistence of the gap between blacks and whites may lay in the surrender by African Americans of the social solidarity that had sustained them in the Jim Crow South. Social capital among African Americans was closely associated with church membership, a phenomenon long recognized by AfricanAmerican sociologists. ${ }^{32}$ Studies of Northern black communities from the 1970 s to

28 Historical Statistics (1999), Table A. 43.

29 R. A. Easterlin, 'Growth and composition of the American Population in the twentieth century', in A Population History of North America, eds. Haines and Steckel (2000), 631-675.

30 Haines and Steckel, (2000), 696-699.

31 M. Humphreys, Malaria: Poverty, Race, and Public Health in the United States (Baltimore, Johns Hopkins, 2001).

32 L. L. Hunt and M. O. Hunt, 'Regional patterns of African American church attendance: Revisiting the semi-involuntary thesis', Social Forces, 78,2 (1999), 779-791. 
the 1990s show a massive drop-off in church attendance. ${ }^{33}$ Recent studies of the health of the black population show that those who attend church regularly are far less likely to die prematurely than those who do not attend at all. ${ }^{34}$ This is particularly true of northern blacks. Those who attend regularly are substantially more likely than the unchurched to seek preventive health care. ${ }^{35}$

Of course the attrition of church attendance among northern blacks requires further explanation. Does it lie in the failure of the generation of migrants to find opportunity in the North? Or is it a product of the disaffection of Northern-born blacks? In either case, however, those who have maintained their religious social capital enjoy better health than those who no longer value it.

The condition of America's central cities, paradoxically, did not have the same effect on immigrants. In the late twentieth century, the largest group were Latinos, who in 2003 became more numerous than African-Americans [each approximately $13 \%$ of the total population]. Between the mid-1930s and the mid-1980s, Latino infant mortality rates, as measured in a Texas county taken to be typical of the country as a whole, fell by a factor of twelve. This decline was twice as rapid as that for the non-Hispanic white population. This led researchers to conclude that Latino infant mortality rates were effectively the same as those for the general population. Scholars used the term "epidemiologic paradox" to describe a situation where the children of poor Latinos were just as well off demographically as those of much wealthier Anglos. ${ }^{36}$ By 1997, the infant mortality rate of Latinos, despite greater risk factors such as less health insurance coverage, short gestation times, and low birth weights, was lower than that for Anglos. ${ }^{37}$ The 2000 census indicated that their health was better than that of average Americans and much better than that of African Americans.

The government's National Vital Statistics System offers two explanations for this phenomenon: The first is that Latino immigrants come from the healthiest and most robust sectors of Latin American society. The other explanation is that U.S. residents of Hispanic origin may return to their country of origin when ill or to

33 L. L. Hunt and M. O. Hunt, 'Race, religion, and religious involvement: A comparative study of whites and African Americans', Social Forces, 80,2 (2001), 605-631.

34 R. A. Hummer et al., 'Religious involvement and U.S. adult mortality', Demography, 36,2 (1999), 273-285.

35 K. Felix-Aaron, D. Levine and H.R. Burstin, 'African American church participation and health care practices', Journal of General Internal Medicine, 18,11 (2003), 908-915; L. M. Chatters, R.J. Taylor and K. D. Lincoln, 'African American religious participation: A multisample comparison', Journal for the Scientific Study of Religion, 38,1 (1999), 132-145.

36 Forbes and Frisbie, (1991).

37 W.P. Frisbie and S. Song, 'Hispanic pregnancy outcomes: Differentials over time and current risk factor effects', Policy Studies Journal, 31,2 (2003), 237-252. 
die. ${ }^{38}$ Whatever the explanation, low Latino mortality rates are the realization of an American preference for providing health care to immigrants comparable to that available to native born whites.

Another social category in which disparities remain is in life expectancy by gender. In 1968, women's life expectancy was 7.5 years longer than men's; by 1992, that advantage slipped to 6.7 years. ${ }^{39}$ This latter decline may be the result of the massive entry of women of childbearing age into the formal work force during the 1970s. The continuing disparity may come from women's more robust genetic makeup.

Understanding the implications of these social transformations, however, requires background on the politics of U.S. health care since Franklin D. Roosevelt's [1933-45] New Deal. Before that time, the federal government played an extremely small role in the provision of health services. Unlike most of the countries of Western Europe there was no government retirement insurance A program to distribute money through the states to poor children and their mothers had been allowed to expire in 1929. The major innovation of the 1920s was a program to build a network of hospitals for World War I veterans. The Great Depression, however, demonstrated that neither private charities nor state and local governments had the resources to alleviate the great distress that Americans were experiencing.

The Social Security Act of 1935 not only offered public retirement insurance for employees, thereby reducing the need for private insurance and fraternal associations, but it also provided assistance for indigent mothers and their dependent children. Another innovation of the Act was that it allocated funds on the basis of need as well as of population. Government relief programs also improved the health of poor southern blacks. ${ }^{40}$ Thus, the government created an entitlement to health care for certain classes of the population: poor mothers, children, and the disabled.

The forty years that followed saw an enormous expansion of government health expenditures. During the 1940s the government created the National Institutes of Health and passed legislation subsidizing hospital construction undertaken by private agencies and local governments. ${ }^{41}$ An increasing number of Americans also

38 A. M. Miniño et al., 'Deaths: Final data for 2000', National Vital Statistics Reports, 50,16 (2002), 4 .

39 Easterlin, (2000).

40 P. V. Fishback, M. R. Haines and S. Kantor, 'The impact of the New Deal on black and white infant mortality in the South', Explorations in Economic History, 38 (2001), 93-122; M. Humphreys, Malaria: Poverty, Race, and Public Health in the United States (Baltimore, Johns Hopkins, 2001).

41 D. M. Fox, Power and Illness: The Failure and Future of American Health Policy (Berkeley, University of California, 1993). 
received coverage for health care from their employers. During the Second World War, the federal government established a tax policy that allowed employers and employees to exclude benefits paid by employers from gross income for the purposes of calculating both individual and corporate taxes. This policy was intended to reduce wartime demand for consumer goods and overall inflation and to narrow the gap between civilian and military wages. This tax exclusion became popular and has continued to the present day, despite criticism of inflation in the costs of medical insurance.

The most important steps in increasing the federal government's role in health care were the Medicare and Medicaid legislation of 1965. Medicare was a new social insurance program for the elderly which covered hospital and physician expenses for all citizens over 65. That entitlement, unfortunately, excluded important items such as preventive care, outpatient pharmaceuticals, and long-term care. Medicaid provided federal matching funds to the states for the provision of medical care to the indigent including the three categories of services omitted from Medicare. Those elderly who could qualify as indigent could therefore obtain total coverage, if they could find a specialist willing to accept government payment levels. ${ }^{42}$ Within two years federal spending on health rose by $10 \%$ of the National Health Expenditures, and out of pocket spending fell by a similar amount.

These new programs, which guaranteed to Americans many of the health services provided by European welfare states, came at a very difficult time in U.S. economic history, the high point of the 1964-75 Vietnam War. Budgetary restrictions inhibited new government spending on health. The government terminated its subsidies for hospital construction. A number of Americans lacked medical insurance: the young, the self-employed, and non-citizens. ${ }^{43}$ For other groups, a number of services, moreover, were not covered: medications and preventive care for seniors, long term health care, and dental insurance, to give three examples. ${ }^{44}$

Other medical fields continued to receive money from the federal government, which invested huge sums in medical research. Well-financed university hospitals developed top of the line procedures to treat the acutely ill. Even though federal investments in health care declined somewhat after the end of the Vietnam War, a combination of public and foundation monies assured a continued improvement in medical technology. ${ }^{45}$ The number of specialists grew as did the number of physicians. The proportion of physicians in the population nearly doubled from

42 L. Brown and M. Sparer, 'Poor program's progress: The unanticipated politics of Medicaid policy', Health Affairs, 22, 1 (2003), 31-44.

43 Starr, (1987).

44 D. M. Fox, 'Health policy and the history of welfare states: A reinterpretation', Journal of Policy History, 10,2 (1998), 239-256.

45 K. M. Ludmerer, Time to Heal: American Medical Education from the Turn of the Century to the Era of Managed Care (New York, Oxford University Press, 1999). 
150 per 100,000 in 1960 to 285 in $1995 .^{46}$ Patients also received care from new categories of health professionals: physician's assistants and nurse practitioners. [See Graph 2.]

Despite increases in federal outlays, a large part of U.S. health care remains in the private sector. To be more precise, most medical expenditures involve both the public and the private sector. The pharmaceutical industry constitutes a case in point. The federal government funds basic research through the National Institutes of Health. Medicaid pays for medications for indigent outpatients, and Medicare and Medicaid pay for in-patient medications. Although the share of pharmaceuticals in national health expenditures fell in the 1960s and 70s, its cost rose again in the 1980s and 1990s. Pharmaceutical manufacturing is in the private sector, and drug prices rose rapidly, particularly after 1995. By 2001, they constituted nearly $10 \%$ of total medical expenditures. Profits depend on production of new pharmaceuticals under patent, which sold in 2000 for an average of 3.4 times the cost of their generic equivalents. After 1996, the industry promoted sales of these new drugs through direct television advertisement to consumers. ${ }^{47}$ The distinction between the marketing of health products and consumer items has been substantially eroded. Pharmaceuticals alone constitute nearly four percent of U.S. GDP.

The public-private partnership in health care leaves little scope for cost controls found in other OECD systems. European countries, particularly those in the E.U. and its predecessors, faced medical inflation directly. As early as the first oil crisis of 1973, governments intervened to control costs. In Britain, the government protected the National Health Service, but engineered cuts in other social programs such as education and housing. ${ }^{48}$ Other countries limited hospital construction in order to optimize use of existing facilities, or raised standards for medical school admission to limit not only the number of doctors but also the expensive procedures they performed. Still others restricted the pharmaceutical industry and encouraged the use of generic drugs. ${ }^{49}$ As a result, health expenditures have remained below $10 \%$ of GDP in the E.U., while they have risen to over $14 \%$ in the U.S. $^{50}$

46 Historical Statistics (1999), Table A25.

47 D. H. Kreling, D. A. Mott and J. B. Wiederholt, Prescription Drug Trends: A Chartbook Update (Menlo Park, CA, Kaiser Family Foundation, 2001).

48 R. Klein, The New Politics of the NHS (Third Edition, Harlow, Longman, 1995), 98.

49 B. Abel-Smith, Cost Containment in Health Care. Occasional Papers on Social Administration 73 (London, Bedford Square Press, 1984), 1-17.

50 L. Paquy, Les systèmes européens de protection sociale en perspective (2003). [http://phoenixtn.net/monographs.jsp]; K. Levit, et al., 'Trends in U.S. health care spending, 2001', Health Affairs, 22,1 (2003), 154-164. 
Figure 5. Prescription drugs as a proportion of NHE and GDP 1960-2000.

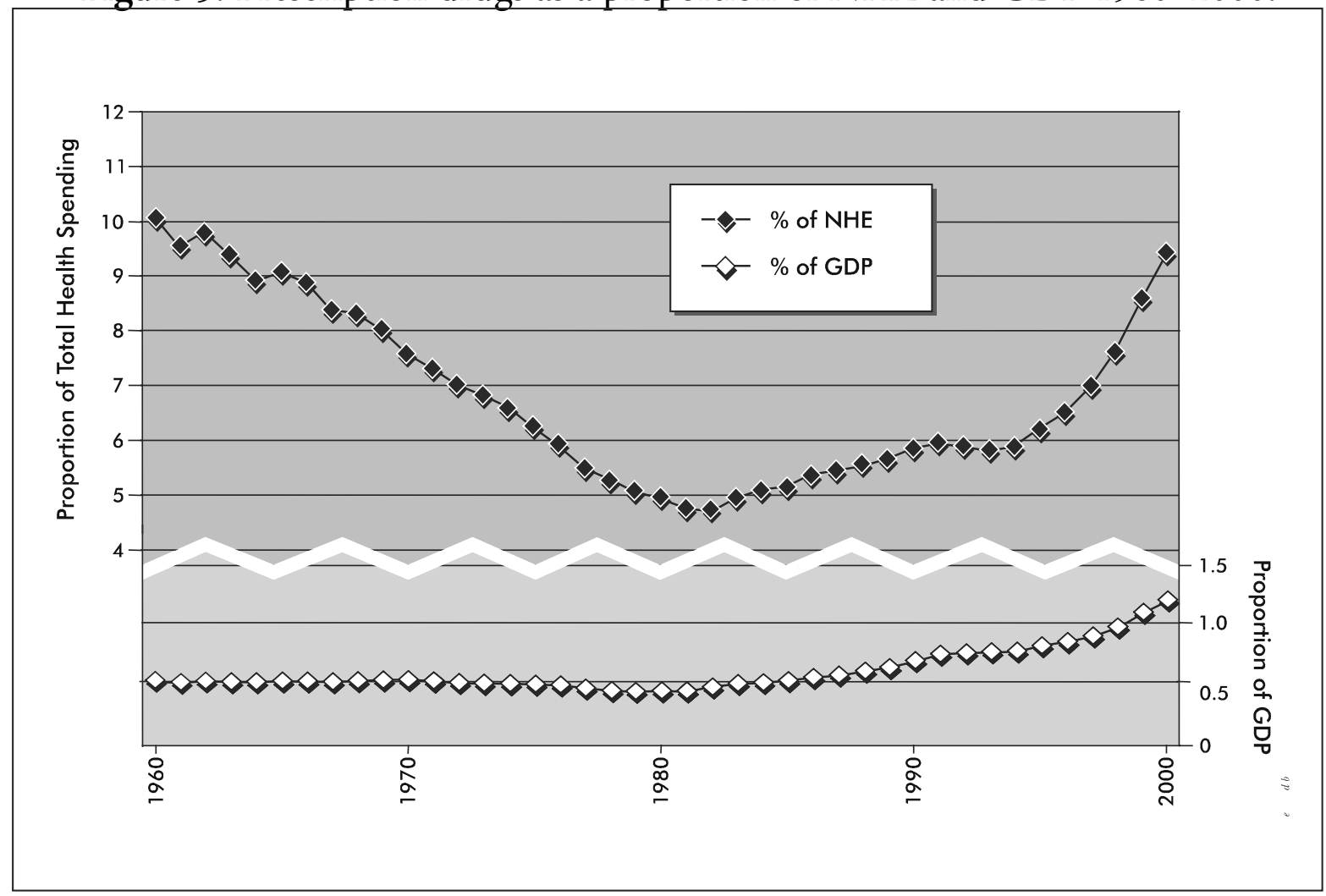

Source: National Health Expenditures, 2002, Center for Medicare and Medical Services, Office of the Actuary, National Health Statistics Group.

Efforts to control various elements in American health costs have been tried and failed. In the 1970s, a number of state legislatures attempted to control hospital costs by restricting new construction, which then amounted to about $40 \%$ of total health care. They required hospitals to obtain certificates of need before expanding their capacities. These measures immediately evoked harsh criticism and, after about 1980, most were repealed. In 1993-94, the Clinton administration attempted to curb the power of insurance companies that were then establishing Health Maintenance Organizations to ration health procedures in order to lower total costs. This, too, elicited a furious response and was rejected by Congress.

By the 1990s, all major elements in American health care were growing simultaneously. The five major providers in the U.S. system are hospitals (32\% of total costs), physicians (22\%), pharmaceuticals (10\%), nursing homes (7\%), and private medical insurance companies $(6 \%)$.

The combination of higher pharmaceutical costs, higher hospital costs, and increased salary costs also strained the resources of all levels of government. ${ }^{51}$ By 2001, health costs were consuming 14.1\% of the Gross Domestic Product. Indeed,

51 Abel-Smith, (1984). 
Figure 6. National health expenditures as a proportion of the GDP.

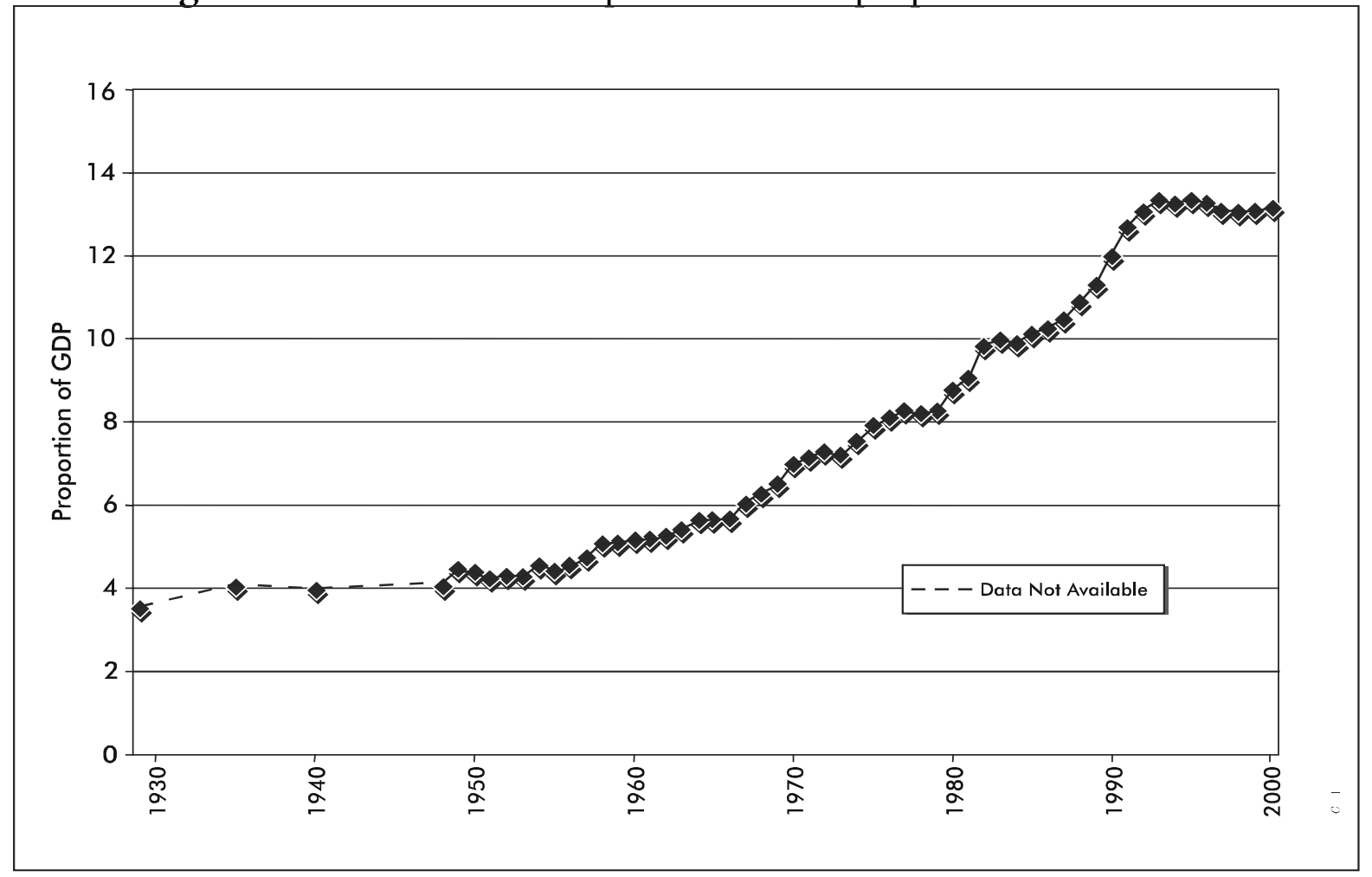

Source: National Health Expenditures, 2002, Center for Medicare and Medical Services, Office of the Actuary, National Health Statistics Group.

the public sector, which includes the federal government [31\%], the state governments [16\%] and tax revenues [10\%] now accounts for 57 percent of all health costs. ${ }^{52}$

This increase in cost has altered the relationship between different levels of government within the federal system. Municipalities, which during the earlier period played such a vital role in public works and public health, are particularly hard hit. They had benefited from federal matching grants but have found that they can no longer provide the array of services that they had once offered. Perhaps part of the problem was the increase in government expenditures during the Vietnam War (1964-75). In the city of Milwaukee, Wisconsin for example, the proportion of the budget allocated to public health fell from 5 percent to 3 percent between 1972 and 1974. States, which had benefited enormously from federal matching grants, also felt themselves strapped for cash. Often they economized by eliminating unsubsidized programs. In Wisconsin, for example, the government in 1972 mandated consolidation of ineffective local programs, eliminating 95 percent of them, and forced counties to close many of the hospitals whose building

52 D. M. Fox and Fronstin, 'Public spending for health care approaches 60 percent', Health Affairs, March/April (2000), 271-273. 
construction the federal government had previously subsidized. ${ }^{53}$ The economic downturn following the attacks on New York and Washington in 2001, has put further pressure on states to reduce their health expenditures.

Health care in the United States is in crisis. The richest country on earth spends one-seventh of its wealth on health care and still leaves 15 percent of its population uninsured. The elderly are frequently forced to choose between food and pharmaceuticals. Many have abandoned biomedicine altogether for the Complementary and Alternative Medicine used by so many Americans in the $19^{\text {th }}$ century. One survey shows that in any given month $6.5 \%$ of the U.S. population consults a non-biomedical healer. ${ }^{54}$

Not everyone thinks that government intervention will satisfy America's unmet health needs. Some look nostalgically back to fraternal organizations to offer protection now provided by government. ${ }^{55}$ Legislation recently enacted by Congress to provide Medicare coverage for preventive procedures and outpatient pharmaceuticals bans the Federal government from negotiating with manufacturers in order to control costs. It also subsidizes private insurers to compete with the Medicare system. This effort to privatize Medicare will most likely raise still further the cost of medical care. It is difficult to see how expensive private services can supplant cheaper public ones.

American health care is a dynamic and complex system. More than that of most other OECD members it embraces both the private and the governmental. At its summit it offers medical procedures unavailable anywhere else in the world. It offers services to the very poor, but often neglects the working poor. Despite its goal of equitable coverage for all, it still fosters substantial differences in health across race and gender. One can only hope that efforts to reform the system eventually result in better coverage for all rather than the attenuation of services.

Bruce Fetter is Professor of History at the University of Wisconsin-Milwaukee, Milwaukee, WI 53201, USA.

53 J. Chapin and B. Fetter, 'Performance-based contracting in Wisconsin public health: Transforming state-local relations', Milbank Quarterly, 80,1 (2002), 97-124.

54 L. Green et al., 'The ecology of medical care revisited', New England Journal of Medicine, 344,26 (2001), 2021-25.

55 D. Beito et al., The Voluntary City: Choice, Community, and Civil Society (Ann Arbor, University of Michigan Press, 2002). 


\section{References.}

Abel-Smith, B., Cost Containment in Health Care. Occasional Papers on Social Administration 73 (London, Bedford Square Press, 1984).

Apple, R., Reaching Out to Mothers: Public Health and Child Welfare. Evening Lecture Series 5 (Sheffield, European Association for the History of Medicine and Health Publications, 2002).

Beito, D., From Mutual Aid to the Welfare State: Fraternal Societies and Social Services, 1890-1967 (Chapel Hill, University of North Carolina Press, 2000).

Beito, D. et al., The Voluntary City: Choice, Community, and Civil Society (Ann Arbor, University of Michigan Press, 2002).

Brown, L. and Sparer, M., 'Poor program's progress: The unanticipated politics of Medicaid policy', Health Affairs, 22,1 (2003), 31-44.

Cain, L. P. and Rotella, E. J., 'Death and spending: Urban mortality and municipal expenditure on sanitation', Annales de démographie historique, 2001-1: 139154 (2001).

Chapin, C., 'Variation in type of infectious disease as shown by the history of smallpox in the United States, 1895-1912', Journal of Infectious Diseases, 13,2 (1913), 171-196.

Chapin, C., 'Permanency of the mild type of smallpox', Journal of Preventive Medicine, 6 (1932), 273-320.

Chapin, J. and Fetter, B., 'Performance-based contracting in Wisconsin public health: Transforming state-local relations', Milbank Quarterly, 80,1 (2002), 97-124.

Chatters, L. M., Taylor, R. J. and Lincoln, K. D., 'African American religious participation: A multi-sample comparison', Journal for the Scientific Study of Religion, 38,1 (1999), 132-145.

Committee on the Costs of Medical Care 1932, Medical Care for the American People (Chicago, University of Chicago Press).

Condran, G., 'Declining mortality in the United States in the late nineteenth and early twentieth centuries', Annales de Démographie Historique (1987), 119-141.

Dublin, L. I., Lotka, A. J., and Spiegelman, M., Length of Life: A Study of the Life Table (New York, Ronald Press, 1949).

Easterlin, R. A., 'Growth and composition of the American Population in the twentieth century', in Haines and Steckel (2000), 631-675.

Felix-Aaron, K., Levine, D. and Burstin, H. R., 'African American church participation and health care practices', Journal of General Internal Medicine, 18,11 (2003), 908-915. 
Fishback, P. V., Haines, M. R., and Kantor, S., 'The impact of the New Deal on black and white infant mortality in the South', Explorations in Economic History, 38 (2001), 93-122.

Forbes, D. and Frisbie, W. P., 'Spanish surname and Anglo infant mortality: Differentials over half a century', Demography, 28,4 (1991), 639-660.

Fox, D. M., Power and Illness: The Failure and Future of American Health Policy (Berkeley, University of California, 1993).

Fox, D. M., 'Health policy and the history of welfare states: A reinterpretation', Journal of Policy History, 10,2 (1998), 239-256.

Fox, D. M., and Fronstin, 'Public spending for health care approaches 60 percent', Health Affairs, March/April (2000), 271-273.

Frisbie, W. P. and Song, S., 'Hispanic pregnancy outcomes: Differentials over time and current risk factor effects', Policy Studies Journal, 31,2 (2003), 237-252.

Green, L. et al., 'The ecology of medical care revisited', New England Journal of Medicine, 344,26 (2001), 2021-25.

Gutmann, Myron P. et al., 'Intra-ethnic diversity in Hispanic child mortality, 1890-1910', Demography, 37,4 (2000), 467-475.

Haines, M. R., 'The white population of the United States, 1790-1920', in Haines and Steckel (2000), 305-369.

Haines, M. R., 'The urban mortality transition in the United States, 1800-1940', Annales de démographie historique, 2001-1: 33-64 (2001).

Haines, M. R. and Steckel, R. H., A Population History of North America (Cambridge, Cambridge University Press, 2000), Table A.2.

Historical Statistics of the United States: Millenial Edition. (Preprint. Cambridge, Cambridge University Press, 1999).

Hummer, R. A. et al., 'Religious involvement and U.S. adult mortality', Demography, 36,2 (1999), 273-285.

Humphreys, M., Yellow Fever and the South (Baltimore, Johns Hopkins, 1992).

Humpreys, M., Malaria: Poverty, Race, and Public Health in the United States (Baltimore, Johns Hopkins, 2001).

Hunt, L. L. and Hunt, M. O., 'Regional patterns of African American church attendance: Revisiting the semi-involuntary thesis', Social Forces, 78,2 (1999), 779-791.

Hunt, L. L. and Hunt, M. O., 'Race, religion, and religious involvement: A comparative study of whites and African Americans', Social Forces, 80,2 (2001), 605-631.

Klein, R., The New Politics of the NHS (Third Edition, Harlow, Longman, 1995).

Kreling, D. H., Mott, D. A., Wiederholt, J. B., Prescription Drug Trends: A Chartbook Update (Menlo Park, CA, Kaiser Family Foundation, 2001).

Levit, K. et al., 'Trends in U.S. health care spending, 2001', Health Affairs, 22,1 (2003), 154-164. 
Ludmerer, K. M., Learning to Heal: The Development of American Medical Education (New York, Basic Books, 1985).

Ludmerer, K. M., Time to Heal: American Medical Education from the Turn of the Century to the Era of Managed Care (New York, Oxford University Press, 1999).

Meeker, E., 'The improving health of the United States: 1850-1915', Explorations in Economic History, 9 (1972), 353-373.

Meeker, E., 'The social rate of return on investment in public health, 1880-1910', Journal of Economic History, 34 (1974), 392-421.

Melosi, M. V., The Sanitary City: Urban Infrastructure in America from Colonial Times to the Present (Baltimore, Johns Hopkins, 2000).

Miniño, A. M. et al., 'Deaths: Final data for 2000', National Vital Statistics Reports, 50,16 (2002).

Mullan, F., Plagues and Politics: The Story of the United States Public Health Service (New York, Basic Books, 1989).

Paquy, L., Les systèmes européens de protection sociale en perspective (2003). [http://phoenixtn.net/monographs.jsp].

Putnam, R., Bowling Alone: The Collapse and Revival of American Community, (New York: Simon \& Schuster, 2000).

Riley, J. C., Sickness, Recovery, and Death (Iowa City, University of Iowa Press, 1989).

Rosenkrantz, B. G., Public Health and the State: Changing Views in Massachusetts (Cambridge MA, Harvard, 1972).

Southall, H., 'Ageing, health and ending with: A study of life cycle and life chances among 19th century British artisans'. Presented to the International Congress of Historical Sciences, Beijing (1995).

Starr, P., The Social Transformation of American Medicine (New York, Basic Books, 1987).

Steckel, R. H., 'The African American population of the United States, 1790-1920', in Haines and Steckel (2000), 433-481.

White, K. M. and Preston, S. H., 'How many Americans are alive because of twentieth-century improvements in mortality?', Population and Development Review, 22,3 (1996), 415-429.

Young, J. H., The Toadstool Millionaires: A Social History of Patent Medicine in America before Federal Regulation (Princeton, Princeton University Press, 1961). 